\title{
Rangeland Resources of North America
}

What are rangelands?

Where do rangelands occur?

What goods and services are drived from rangelands?

Where do I get more information about U.S. rangeland resources?

$\begin{aligned} \text { For more } & \text { Society for Range Management } \\ \text { information, } & 445 \text { Union Blvd., Suite } 230 \\ \text { contact: } & \text { Lakewood, CO } 80228 \\ & \text { Ph. 303-986-3309 } \\ & \text { Fax: 303-986-3892 } \\ & \text { srmden@ix.netcom.com }\end{aligned}$
grazing industries, cultural activities. sources.

srmden@ix.netcom.com
Rangelands are a type of land on which the natural vegetation is dominated by grasses, forbs, and shrubs and the land is managed as a natural ecosystem.

Rangelands occupy about $40 \%$ of the land area of the United States and the world. Rangelands include Great Plains grasslands, savannas in Texas and Florida, shrublands in the Great Basin, Alaska tundra, alpine meadows, wetlands and Southwestern deserts.

As such, rangelands occur in every state and are the dominant type of land in the arid and semi-arid regions. For example, $80 \%$ of the lands of Nevada are classified as rangelands whereas only $7 \%$ of the lands of Maine are classified as rangelands.

Rangelands are multiple use resources that serve as:

- wildlife habitat for a wide array of game and non-game species,

- a source of high quality water, clean air, and open spaces,

- a setting for recreational hiking, camping, fishing, hunting and nature experiences,

- the foundation for the low-input, fully renewable food and fiber production systems of

- natural carbon sequestration systems that reduce atmospheric $\mathrm{CO}^{2}$ concentrations,

- habitat for threatened and endangered species, and a setting for an array of social and

Because of the diversity of goods and services derived from rangelands, they are linked closely to the economic well-being of many communities.

The Society for Range Management is a professional society committed to advancing the art and science of rangeland management as a means of conserving rangeland re-

Its 4,000-plus members include ecologists, taxonomists, conservationists, hydrologists, soil, plant, animal, and wildlife scientists, economists and other social scientists, ranchers, farmers and others interested in the conservation of rangeland resources. The glue that holds the Society together is the membership's excitement for learning experiences, and its appreciation and love for the resource and the people who manage it.

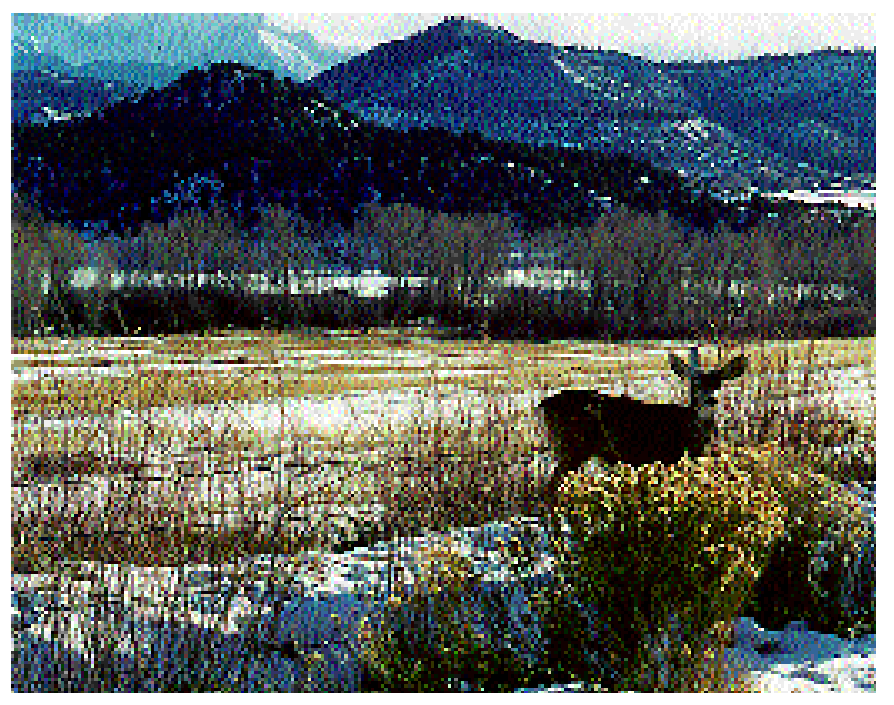

